\title{
Master Franchising as Foreign Entry Mode: Evidences from the Spanish Franchise System
}

\author{
Veronica Baena \\ Department of Business Administration, European University of Madrid, Calle Tajo, s/n Urb. El Bosque, \\ Villaviciosa de Odón, 28670 Madrid, Spain \\ Correspondence should be addressed to Veronica Baena, veronica.baena@uem.es
}

Received 25 April 2012; Accepted 13 August 2012

Academic Editors: B. Junquera, J. Menon, and M. D. Ramirez

Copyright ( $(2012$ Veronica Baena. This is an open access article distributed under the Creative Commons Attribution License, which permits unrestricted use, distribution, and reproduction in any medium, provided the original work is properly cited.

The present study examines how a number of market conditions may constrain entry mode choice into Middle East nations. Specifically, this paper focuses on master franchising and analyzes the determining factors in this entry mode decision. A quantitative approach was applied to a sample of Spanish franchisors operating through 96 franchisee outlets across 6 Middle East countries in January 2010. They are Bahrain, Cyprus, Israel, Jordan, Saudi Arabia, and United Arab Emirates. Findings show the importance of a number of host country's features (economic development, corruption, and efficiency of contract enforcement). The scant theoretical or empirical attention given to the topic of foreign entry mode choice via franchising has usually been examined from a U.S. base and focused on developed markets. To fill this gap, the present study analyzes the international spread of the Spanish franchise system-ranked fifth worldwide both in terms of the number of franchisors $(1,019)$ and the quantity of franchisee outlets $(65,026)$ - into the Middle East.

\section{Introduction}

The entry mode choice is the selection of an institutional arrangement for organizing and conducting business transactions. It determines the extent to which the firm gets involved in developing and implementing the strategy in the foreign markets, the level of control the firm enjoys its business operations, and the degree to which it succeeds in the target market. The entry mode choice is then one of the most critical decisions in international marketing [1-6].

Many forms of entry are available. Most literature distinguishes between equity and nonequity modes to enter foreign markets. Equity modes involve companies taking some degree of ownership of the market organizations involved, including wholly owned subsidiaries and joint ventures. In contrast, nonequity modes do not involve ownership and include exporting in combination with some forms of contractual arrangements such as licensing or franchising [6]. Choosing one or another entry mode may have enormous strategic consequences for the firm's performance and survival $[1,7]$.
Regarding nonequity modes of entry, franchising can be defined as a licensing agreement between the franchisor and the franchisee, whereby the former grants the permission for the use of his trademarks, ideas, patent of goodwill in lieu of royalty or some other consideration by the franchisee [8]. This business format offers numerous advantages, as compared to chain-ownership, such as having ownermanagers who are motivated in making their individual stores succeed. The ability to access the local knowledge of the franchisees, who often are members of their local community, is another advantage [9]. As a result, we can argue that franchising is one of the most preferred strategies in international expansion as it provides flexibility and economies of scale to worldwide operations [7, 10-12].

Nevertheless, despite in recent years, the literature highlighted the need of examining the scope of franchising from an international standpoint, the academic attention given to this topic still remains limited $[11,13,14]$. Specifically, the literature on franchising has fully covered issues such as why firms should organize as a franchise chain and engage franchisee, franchising efficiency, and the relationship 
between franchisor and franchisee. In contrast, international franchising has generally received limited academic attention $[11,13,14]$. Furthermore, there is a great need for a deeper explanatory model of international diffusion via franchising across markets, one that can explore this issue by focusing on franchising systems other than those from the U.S. and British model $[5,14-16]$.

The present study attempts to cover this gap by exploring the effect of a set of franchisor and host country characteristics in one of the entry mode that franchisors may adopt (master franchising) to enter into Middle East. This region encompasses Western Asia and Northern Africa, an area of approximately $2,792,823 \mathrm{~km}^{2}$. As of 2010 , its population was estimated at 2,242,342 people, and GDP at 2,840,892 billion U.S. dollars. Furthermore, the Middle East region's significant stocks of crude oil gave it new strategic and economic importance in the 20th century. Particularly, the estimated oil reserves, especially in Saudi Arabia and Iran, are some of the highest in the world, and the international oil cartel (OPEC) is dominated by Middle Eastern countries. Nevertheless, despite the fact that the U.S., Canada, and parts of Western Europe have reached domestic market saturation [11], Middle East markets remain relatively untapped. Thus, research in international management in this context is very limited. This is surprising given that, according to the CIA World Factbook Report published in 2010, all nations in the Middle East are maintaining a positive rate of growth.

More specifically, the purpose of this paper is to explore the role of the franchisors' international experience, brand awareness, and industry type (product versus service) in conjunction with a number of market conditions (cultural and geographical distance, host country's transparency, economic development, and efficiency of contract enforcement) as driving factors that may influence the entry mode via master franchising in the Middle East. In order to advance our understanding, this study focuses on the Spanish franchise system, which since 2008 has been fifth worldwide both in terms of the number of franchisors $(1,019)$ and the quantity of franchisee outlets $(65,026)$. Also, as highlighted by the Spanish Franchise Association, it has presence in 112 foreign countries through 172 chains with total of 10,186 outlets established overseas in early 2010.

The remainder of this paper is as follows. The following section considers the previous literature and sets out the hypotheses of the study. Next, the characteristics of the sample are reported and the methodology is presented. Empirical results are discussed in the subsequent section. Finally, the study closes with a discussion of our contributions and implications for theory and practice, limitations, and suggestions for future research.

\section{Literature Review and Hypotheses Development}

As stated in the Section 1, companies willing to expand their business abroad via franchising can develop an agreement with a local agent (franchisee) and offer the right to use a trademark in return for a royalty fee. This mode of entry is named direct franchising.

Nevertheless, firms wishing to expand abroad via franchising may also opt for signing a master franchising agreement, the topic of analysis of this study. In particular, this mode of entry refers to the contractual agreement between the franchisor and an independently owned subfranchisor (the master franchisee) to develop a specified number of franchises for the exclusive right to use the business format for a time period in a particular geographical region. Then, master franchisees have the option of developing subfranchisees or opening all units by themselves. In short, the master is the acting franchisor in the target market whose roles include being an empowered franchisee on the one hand, and subfranchisor on the other [3].

One of the major advantages of expanding via master franchising is that the local partner (the master franchisee) understands the political and bureaucratic problems of his/her country far better than his/her foreign partner (the franchisor), and it is also in a better position to negotiate with government agencies and private businesses [17]. Furthermore, the master franchisee can handle cultural differences and help develop local markets through appropriate means of advertising and promotion [3, 18].

Among the multiple approaches to this issue, the transaction cost analysis (TCA) has been the most widely used theory in studies of multinational companies' entry mode choice $[17,19,20]$. It views the firm as a governance structure [21] and proposes that firms will choose an entry mode having the lowest transaction cost [4]. This theory then posits that firms internalize those activities that they can perform more efficiently and outsource others that external providers can perform at a lower cost [1]. Thus, the choice of entry requires a comparison of the coordination cost associated with the internationalization, and the transaction costs arising from the search for, negotiation with, and control of a local market partner [22].

Consequently, as stated in Williamson [23], an interdependent set of transaction costs associated with franchisingout into host markets can be envisaged: (i) monitoring costs; (ii) researching costs to identify and evaluate potential franchise buyers in the target market; (iii) property right protection costs to forbid contracted parties from operating a similar business in a given territory and/or time once the agreement finishes; (iv) servicing costs to transfer the franchisor's technology and know how to franchisees.

Later, we develop a framework based on TCA to infer the variables constraining the foreign entry mode via master franchising, based on a franchisor and host country level perspective.

2.1. Geographical and Cultural Distance. Cultural and geographical distances between the franchisor's home country and host country of the subsidiary add a further dimension to risks inherent to international franchising [24]. They both have been argued to influence entry mode decisions $[3,7,11,15,22]$. 
In particular, geographical distance generates costs related to information collection and communications, which hinders internationalization [25]. Similarly, selection, control, and supervision costs are higher in culturally distant markets, as the information asymmetries and the likelihood of opportunistic behaviour increase. All these issues increase transaction costs [17].

In sum, both geographical and cultural distances between the host and home country induce foreign enterprises to seek local support with the aim of facilitating product adaptation [25]. This increases the likelihood of entering via master franchising, as more help is needed from local contacts, and the potential for cultural misunderstandings. The likelihood of suffering from adverse selection problems is also greater $[7,26]$. Thus, we make the following propositions:

H1: the expansion of franchising across countries with high geographical distance is positively associated with master franchising as entry mode in the Middle East;

H2: the expansion of franchising across countries with high cultural distance is positively associated with master franchising as entry mode in the Middle East.

2.2. International Experience. Franchise chains with stronger international experience are more able to identify the most qualified franchisees. Specifically, greater franchising experience can help the franchisor to select suitable agents [13], by enabling him/her to identify ideal franchisees and rule out requests from interested parties unfamiliar with the local market or its business uses [16]. This lessens adverse selection [27]. It also improves the use of mechanisms for control, monitoring, and market analysis, which reduce the transaction cost of researching and evaluating potential candidates to be franchisees [28-30].

In sum, franchisors with high international experience either do not require the help of a local agent, or they need less of such help [31], as they have enough knowledge of how to do business abroad. As a consequence, internationally experienced franchise chains will tend to avoid entering into foreign markets via collaborative agreements with local agents - that is, master franchisee-as this mode of entry entails sharing the profits with the business partners [4] Based on the previous discussion, we propose the following:

H3: the expansion of franchisors with strong international experience is negatively associated with master franchising as entry mode in the Middle East.

2.3. Corruption. Corruption produces bottlenecks, heightens uncertainty, and exacerbates the information asymmetry problem [32, 33]. As such, corruption acts as an irregular tax on business, increasing transaction costs, and distorting incentives to foreign investment. Many empirical studies provide support for this idea (see, e.g., $[32,34,35]$ ).

Concerning those difficulties, foreign investors look for local partners by providing access to location-specific knowledge and local networks $[2,33]$. We can then argue that franchisors prefer entering into a corrupt country through local partners by transacting with some form of intermediary, who purchases from the franchisor entrant the right to develop their own network of outlets in the host market. Specifically, those agents (called master franchisors) are allowed by the franchise chain to subfranchise and sell the format on to independent subfranchisees in the host market. This mode of entry may help franchisors to prevent moral hazard and adverse selection without requiring site visits and the accompanying travel difficulties [17]. Moreover, entry via master franchising eliminates the need for regional monitoring facilities in global markets [27] and reduces the costs associated with doing business in corrupt countries. Hence, based on the previous discussion we make the following proposition:

H4: the expansion of franchising across countries with low transparency (high corruption) is positively associated with master franchising as entry mode in the Middle East.

2.4. Economic Development. As suggested in previous literature, host market's economic development is another determinant of the entry mode decision [19, 24, 36]. In particular, since franchising is dominated by services or products associated with services, the importance of investing in a viable host economy where people are able to afford them (rather than perform them themselves) is crucial to the growth of business activity via franchising $[3,7,15]$. Moreover, a country's stronger economic development is associated with business growth [11].

Countries with strong economic development usually have less exposure to economic risk [2, 37]. This issue reduces the adverse selection problem and the costs related with monitoring the franchisee's activities and behaviour [7]. It would lead us to hypothesize that franchise chains will support franchising as entry mode in foreign markets with strong economic development. Therefore, based on this discussion, we propose the following:

H5: the expansion of franchising across countries with strong economic development is positively associated with the propensity for master franchising in the Middle East.

\section{Methodology}

3.1. Sample and Data Collection. Data on foreign entry mode via master franchising were obtained from the Spanish franchise system, which from 2008 ranks fifth worldwide for the number of chains $(1,019)$ and franchised outlets $(65,026)$, having presence across 112 foreign countries through 172 Spanish franchisors with a total of 10,186 outlets overseas. In particular, information about the worldwide situation of Spanish franchising in the Middle East was obtained by contacting the Spanish Franchise Association, and the main Spanish franchising Consultant Group: Tormo \& Asociados. We also considered various studies published in the business press, as well as web pages of the main Spanish franchise chains and the most important international franchising associations (International Franchise Association, Global Franchise Network, etc.). As a result, we obtained data on the entry mode adopted in 87 outlets across the 6 Middle East nations where Spanish franchisors are doing business via master franchising ${ }^{1}$. 
TABLE 1: International spread of Spanish franchisors across Middle East in January 2010.

\begin{tabular}{lcc}
\hline Country & Franchisors & Outlets \\
\hline Saudi Arabia & 29 & 132 \\
United Arab Emirates & 17 & 56 \\
Cyprus & 14 & 43 \\
Turkey & 11 & 598 \\
Egypt & 10 & 29 \\
Qatar & 10 & 17 \\
Israel & 8 & 39 \\
Jordan & 8 & 12 \\
Syria & 5 & 10 \\
Bahrain & 5 & 9 \\
Iran & 2 & 2 \\
Iraq & 1 & 1 \\
\hline
\end{tabular}

As shown in Table 1, the international spread of the Spanish franchise system in January 2010 across the Middle East is considerable, both in terms of the number of franchisors (29 chains) and the number of outlets (948 outlets). This international diffusion was conducted via (i) direct franchising; (ii) master franchising; (iii) joint venture; (iv) direct investment ${ }^{2}$. As mentioned above, 87 outlets were established via master franchising in the Middle East, which represent a nine percent percent of total entries (a total of 948) conducted by Spanish franchisors in the Middle East region.

3.2. Dependent Variable. The goal of this study is to assess the effect of the proposed variables on the adoption of master franchise as foreign entry mode by franchisors in their international expansion. Consequently, the dependent variable was computed by considering the total number of outlets established via master franchising (MASTER) by each franchise chain across the Middle East.

3.3. Independent Variables. The geographical distance (GEODIST) was drawn from the kilometre distance between the capital of the franchisor's home country (Madrid, by default) and the capital of the nation where the outlet is located. In the data set, this variable ranges from 3,549 (Israel) to 5,716 (Saudi Arabia). Cultural distance (CULTDIST) was assessed by using Hofstede's [38] work, which updates Hofstede's [39] study. This study uses Kogut and Singh's [40] index, an approach which has been used very often both in the traditional literature as well as in recent research (see, e.g., $[41,42]$ ).

The international experience of franchise chains is usually defined as the geographical spread of franchising within a foreign country [43]. Therefore, it was assessed by examining the number of outlets each franchisor company has located abroad (OUTLETS). In our dataset, this variable ranged from 70 (Cellulem Block, beauty care chain) to 1,239 outlets (Mango, retail chain) established overseas. However, this measurement has one weakness in that it may not reveal the real degree of international expansion. In particular, the
Spanish franchise chains with more outlets abroad do not always correspond with the franchisors with presence in more foreign countries. In order to deal with this problem, a second variable was created to measure international experience, defined as the number of foreign countries (COUNTRIES) in which each of the Spanish franchisors is doing business. In our dataset this variable ranged from 6 (Pans \& Company, fast food chain) to 100 (Mango, retail chain) nations.

Other host country characteristics considered in this study were measured as follows: the host country's level of corruption (TRANSPAREN) was computed by using the 2010 Transparency International (TI) Index. Highest values correspond to nations showing high transparency (low corruption). In the dataset, it ranks from 1.9 (Saudi Arabia) to 6.6 (Cyprus). In relation to the host market's economic development (MARKET), recent literature has suggested gross domestic product per capita as a proxy variable $[11,24,44]$. Therefore, data published in 2010 by the International Monetary Fund was considered. In our dataset, this variable ranks from US\$5.66 (Jordan) to US $\$ 38.28$ (United Arab Emirates).

3.4. Control Variables. In conjunction with the independent variables mentioned above, this paper controls for the host country's efficiency of contract enforcement. It was assessed by following the evolution of a disputed sale of goods, tracking the time, cost, and number of procedures involved from the moment the plaintiff files the lawsuit until actual payment. Specifically, as suggested in Djankov et al. [45], this work uses the three indicators developed by the Doing Business Index published in 2010 by the World Bank Group:

(i) number of procedures from the moment the plaintiff files a lawsuit in court until the moment of payment (PROCEDURE),

(ii) time elapsed (calendar days) in resolving the dispute (DURATION), and

(iii) cost in court fees and attorney fees, where the use of attorneys is mandatory or common, expressed as a percentage of the debt value (COST).

In an attempt to shed light on the conditions favoring master franchising in the Middle East, it was also controlled for a set of franchisors' characteristics. Specifically, the franchise chain's brand awareness and type of industry-service versus product were considered. The brand awareness of Spanish franchisors (BRAND) was assessed by using data from the last study conducted by the Forum of Leading Spanish Brands (Foro de Marcas Renombradas Españolas (FMRE)-http://www.brandsofspain.com/). The franchise chain's industry type (ACTIVITY) was measured with a binary variable that takes a value of 0 when it is product based, and 1 when the business is service based by using the classification compiled by main Spanish franchising Consultant Group: Tormo \& Asociados. 


\section{Results}

The descriptive statistics are reported in Table 2.

Subsequently, the correlation matrix among variables is reported in Table 3.

The analysis of the hypotheses proposed in this study was conducted by computing OLS regression analysis. Those variables that were not normally distributed entered the model in logarithmic form. To test the existence of collinearity among the variables, the tolerance and variance inflation factor (VIF) were computed. None was statistically significant, suggesting that collinearity was not a problem in our regression models. For additional confirmation of these results, we calculated the determinant of the correlation matrix, finding a value of 1 , and we were thus able to rule out problems of multicollinearity. Results are shown in Table 4.

As shown, franchise chains will opt for entering via master franchising in those markets characterized by high corruption (TRANSPAREN), international experience (OUTLETS), and efficiency of contract enforcement (PROCEDURE, DURATION, and COST). Consequently, results support hypotheses $\mathrm{H} 3$ and $\mathrm{H} 4$ at the 0.1 and 0.05 level respectively. Contrary to expectations, entries via master franchising are preferred if host country's economic development (MARKET) is high. So, hypothesis H5 was not supported.

Moreover, master franchising entry mode is favoured by franchisors doing business in nations characterized by high geographical and cultural distance with the home market. Nevertheless, those findings were not statistically significant and thus, hypotheses $\mathrm{H} 1$ and $\mathrm{H} 2$ were not supported in this study. Findings also reveal that the expansion of servicebased companies is positively associated with master franchising as entry mode. In this sense, company whose business line is selling products instead of services tends to have more structured control processes. Thus, such companies can easily show the franchisee how to carry out various aspects of the business, while controlling for compliance, managing inventory, and so forth. On the other hand, in service-based franchises, the human factor is much more important and, therefore, more difficult to control and supervise with formal mechanisms. Therefore, free riding potential problems are likely to appear. As a consequence, given that servicebased franchise chains spend more resources in monitoring activities as compared to product based ones, one would assume that they would opt to enter foreign markets through an intermediary (master franchisor), someone who knows the franchisees and understands the specific characteristics of the host country. However, as this relation was not statistically significant, the above conclusion should be taken with caution.

\section{Discussion and Conclusion}

The choice of entry into a foreign market is an important business decision. It determines a firm's strategic orientations, the amount of control the firm enjoys over its operations, and the degree to which the firm succeeds in foreign markets [19]. Not surprisingly, entry mode choice has been a topic of considerable inquiry in the literature.
However, this issue has usually been discussed within the context of Western nations rather than other regions like the Middle East. Such region ranges from being very poor (such as Gaza and Yemen) to extremely wealthy nations. Specifically, according to the World Bank's World Development Indicators database published on July 1, 2009, Turkey (\$ $794,228,000,000)$, Saudi Arabia $(\$ 467,601,000,000)$, and Iran $(\$ 385,143,000,000)$ were the three largest Middle Eastern economies in 2008 in terms of the GDP. In regards to the GDP per capita, Qatar $(\$ 93,204)$, the UAE $(\$ 55,028)$, Kuwait $(\$ 45,920)$, and Cyprus $(\$ 32,745)$ are the highest ranking countries. In short, most Middle East countries have per capita GDPs greater than that of China in 2009. However, little is known about the factors favouring entry mode in that region.

The scant theoretical and empirical attention given to entry mode choice by international franchisors has been examined from a U.S. base. Then, there is a great need for a deeper explanatory model of international diffusion, one that can explore this issue by focusing on franchising systems other than those from the U.S. model. In order to advance our understanding, we focus on the Spanish franchise system, which since 2008 has been fifth worldwide both in terms of the number of franchisors and the quantity of franchisee outlets. Additionally, in an attempt to add incremental value to this work, this study focuses on master franchising as foreign entry mode choice, which is among the most prevalent mode of entry into new markets by franchise chains $[3,46]$. Examples of famous franchisors using only master franchising in international markets abound and include Oxford Learning Center (Educational Services), Kentucky Fried Chicken (food services) and MRI Worldwide (business services), among others.

When multinational companies expand into a foreign market by establishing a local subsidiary, they must decide on the control and percentage of ownership they desire in the foreign venture [47]. The choice of a particular partner influences the mix of skills and resources available and thus, the firm's ability to achieve its strategic objectives. In particular, improper partner selection may result in increased management conflicts and slow decision-making process [8]. Regarding our findings, franchisors seeking to expand their business in nations characterized by low transparency will opt for master franchising, as highlighted in recent literature [17]. This is the case, for instance, of Bershka and Zara (fashion retail chain), which entered into Saudi Arabia by signing an agreement with the master franchisor Fawaz Alhokair Group, one of the largest retail group in the Middle East.

Efficiency of contract enforcement is especially important for franchise chains as their most valuable asset are intangibles such as brand names, patents, and trademarks, that can be misused by opportunistic foreign franchisees if not adequately protected [24]. Then, chains entering foreign markets characterized by low efficiency of contract enforcement will opt for a master franchising agreement to overcome the liability of foreignness and reduce the risks inherent to the business operations. The expansion of Pressto (dry cleaning chain) in Israel through a master 
TABLe 2: Descriptive statistics.

\begin{tabular}{lcccc}
\hline Variables & Minimum & Maximun & Mean & Standard deviation \\
\hline Master & 1.000 & 14.000 & 5.824 & 4.246 \\
Geodist & $3,549.000$ & $5,716.000$ & $4,608.719$ & 978.906 \\
Cultdist & 2.210 & 4.360 & 2.552 & 0.963 \\
Transparen & 1.900 & 6.600 & 4.593 & 1.555 \\
Market & 5.660 & 38.280 & 15.510 & 13.625 \\
Procedure & 35.000 & 50.000 & 44.230 & 5.463 \\
Duration & 607.000 & $1,011.000$ & 703.659 & 148.543 \\
Cost & 2.000 & 31.200 & 9.468 & 9.468 \\
Activity & 0.000 & 1.000 & 0.296 & 0.465 \\
Brand & 32.100 & 86.800 & 42.413 & 25.928 \\
Outlets & 70.000 & $1,239.000$ & 194.942 & 439.129 \\
\hline
\end{tabular}

TABle 3: Correlation matrix.

\begin{tabular}{|c|c|c|c|c|c|c|c|c|c|c|c|c|}
\hline & Master & Procedure & Duration & Cost & Transparen & Market & Geodist & Cultdist & Activity & Brand & Outlets & Countries \\
\hline Master & 1.000 & 0.009 & 0.190 & 0.104 & -0.025 & -0.018 & 0.051 & 0.088 & 0.064 & 0.201 & -0.233 & -0.136 \\
\hline Procedure & & 1.000 & 0.704 & -0.515 & -0.601 & -0.432 & -0.343 & -0.797 & 0.174 & 0.059 & -0.082 & -0.197 \\
\hline Duration & & & 1.000 & -0.478 & -0.500 & -0.530 & -0.233 & -0.493 & 0.111 & -0.111 & -0.104 & -0.184 \\
\hline Cost & & & & 1.000 & 0.588 & 0.322 & -0.039 & 0.272 & 0.054 & -0.143 & -0.038 & 0.008 \\
\hline Transparen & & & & & 1.000 & 0.902 & 0.210 & 0.676 & -0.219 & 0.022 & 0.055 & 0.112 \\
\hline Market & & & & & & 1.000 & 0.317 & 0.571 & -0.203 & 0.118 & 0.060 & 0.089 \\
\hline Geodist & & & & & & & 1.000 & 0.624 & -0.034 & 0.122 & 0.071 & 0.052 \\
\hline Cultdist & & & & & & & & 1.000 & -0.199 & 0.115 & 0.162 & 0.193 \\
\hline Activity & & & & & & & & & 1.000 & -0.265 & -0.406 & -0.604 \\
\hline Brand & & & & & & & & & & 1.000 & 0.658 & 0.617 \\
\hline Outlets & & & & & & & & & & & 1.000 & 0.695 \\
\hline Countries & & & & & & & & & & & & 1.000 \\
\hline
\end{tabular}

franchise agreement with the entrepreneur Ysaac Benjamin Nahon illustrates this choice. Results also confirm that firms lacking significant international experience will opt for master-franchising investment as entry mode to get access to location-specific knowledge in addition to local networks $[2,33]$.

Moreover, this work reveals a negative association between the use of master franchising and high levels of a host country's economic development. We can then argue that a country's stronger economic development is associated with business growth [11]. Thus, as economies become more affluent, there is a greater shift to services which, as shown by Hoffman and Preble [43], provide more opportunities for firms to expand. In addition, as those nations show less exposure to economic and business risks [2], franchisors willing to enter into them do not need alliances with local partners (as master franchisees), or they need less of such help. This gives franchisors the opportunity to enter those markets via equity - joint venture or direct investment, and, therefore, create an entirely new organization that meets its own requirements.

In sum, the results obtained in this study prove that a number of franchisors' characteristics and host country features influence the choice to enter in the Middle East via master franchising. To the author's knowledge, no previous study exists that explore this topic. This will be our contribution. Additionally, it is developed and tested an explanatory model that can be useful not only for academics but also for franchisors with little experience willing to expand their business in this region.

\section{Limitations and Directions for Future Research}

The present study has a number of limitations. Firstly, this study only refers to Spanish franchisors. We encourage for a future study to analyze chains coming from other nations and test whether the findings obtained in this study can be generalized to every franchise chain. Secondly, more work is needed to identify additional variables favouring master international franchising. Thirdly, this study identifies certain firm and country factors that influence master international franchising, but it does not endeavour to classify the relative importance of these variables. While it was not an objective of this work to find such relative importance (if any), further research may be conducted to assign a numerical weight to each factor as indication of their relative importance in the choice of foreign entry mode.

Lastly, this study identifies some firm and country factors that may influence the foreign entry via master franchising in 
[12] V. Baena, "Market conditions driving international franchising in emerging countries," International Journal of Emerging Markets, vol. 7, no. 1, pp. 49-71, 2012.

[13] B. Quinn and A. M. Doherty, "Power and control in international retail franchising: evidence from theory and practice," International Marketing Review, vol. 17, no. 4-5, pp. 354-372, 2000.

[14] A. M. Doherty, "The internationalization of retailing: factors influencing the choice of franchising as a market entry strategy," International Journal of Service Industry Management, vol. 18, no. 2, pp. 184-205, 2007.

[15] I. Alon and D. McKee, "Towards a macro environmental model of international franchising," Multinational Business Review, vol. 7, pp. 76-82, 1999.

[16] B. Elango, "Are franchisors with international operations different from those who are domestic market oriented?" Journal of Small Business Management, vol. 45, no. 2, pp. 179193, 2007.

[17] V. Baena, "The effect of corruption on global franchising in emerging markets," International Journal of Business and Emerging Market, vol. 3, no. 1, pp. 57-74, 2011.

[18] S. C. Peng and R. T. Justis, "Franchise management in East Asia," The Academy of Management Perspectives, vol. 4, no. 2, pp. 75-85, 1990.

[19] P. Deng, "Determinants of full-control mode in China, an integrative approach," American Business Review, vol. 21, no. 1, pp. 113-123, 2003.

[20] V. Sharma and M. Erramilli, "Resource-based explanation of entry mode choice," Journal of Marketing Theory and Practice, vol. 12, pp. 1-18, 2004.

[21] O. E. Williamson, Economic Institutions of Capitalism, Free Press, New York, NY, USA, 1985.

[22] J. F. Puck, D. Holtbrügge, and A. T. Mohr, "Beyond entry mode choice: explaining the conversion of joint ventures into wholly owned subsidiaries in the People's Republic of China," Journal of International Business Studies, vol. 40, no. 3, pp. 388-404, 2009.

[23] O. E. Williamson, Markets and Hierarchies, Analysis and Antitrust Implications, Free Press, New York, NY, USA, 1975.

[24] E. H. Aliouche and U. A. Schlentrich, "Towards a strategic model of global franchise expansion," Journal of Retailing, vol. 87, no. 3, pp. 345-365, 2011.

[25] Y. R. Chen, C. Yang, S. M. Hsu, and Y. D. Wang, "Entry mode choice in China's regional distribution markets: institution vs. transaction costs perspectives," Industrial Marketing Management, vol. 38, no. 7, pp. 702-713, 2009.

[26] D. H. B. Welsh, I. Alon, and C. M. Falbe, "An examination of international retail franchising in emerging markets," Journal of Small Business Management, vol. 44, no. 1, pp. 130-149, 2006.

[27] C. M. Sashi and D. P. Karuppur, "Franchising in global markets: towards a conceptual framework," International Marketing Review, vol. 19, no. 5, pp. 499-524, 2002.

[28] S. Eroglu, "The internationalisation process of franchise systems, a conceptual model," International Marketing Review, vol. 9, pp. 19-30, 1992.

[29] S. A. Shane, "Why franchise companies expand overseas," Journal of Business Venturing, vol. 11, no. 2, pp. 73-88, 1996.

[30] D. Dow and J. Larimo, "Challenging the conceptualization and measurement of distance and international experience in entry mode choice research," Journal of International Marketing, vol. 17, no. 2, pp. 74-98, 2009.
[31] S. Agarwal and S. N. Ramaswami, "Choice of foreign market entry mode, Impact of ownership, location, and internalization factors," Journal of International Business Studies, vol. 23, pp. 1-27, 1992.

[32] B. S. Javorcik and S. J. Wei, "Corruption and cross-border investment in emerging markets: firm-level evidence," Journal of International Money and Finance, vol. 28, no. 4, pp. 605-624, 2009.

[33] N. M. Jensen, Q. Li, and A. Rahman, "Understanding corruption and firm responses in cross-national firm-level surveys," Journal of International Business Studies, vol. 41, no. 9, pp. 1481-1504, 2010.

[34] L. E. Brouthers, Y. Gao, and J. P. McNicol, "Corruption and market attractiveness influences on different types of FDI," Strategic Management Journal, vol. 9, no. 6, pp. 673-680, 2008.

[35] M. Habib and L. Zurawicki, "Corruption and foreign direct investment," Journal of International Business Studies, vol. 33, no. 2, pp. 291-307, 2002.

[36] S. H. Rahman, "International market selection process, an investigation of the relevant of business operating environment," Journal of International Business Research, vol. 5, no. 1, pp. 73-86, 2006.

[37] M. Tétrault, "Economic conditions: doing business in the Middle East: politics and economic crisis in Jordan and Kuwait," The Middle East Journal, vol. 59, no. 2, pp. 323-324, 2005.

[38] G. Hofstede, Culture's Consequences, Comparing Values, Behaviours, Institutions, and Organizations Across Nations, Sage Publications, Thousand Oaks, Calif, USA, 2001.

[39] G. Hofstede, Culture's Consequences, International Differences in Work-Related Values, Sage Publications, Beverly Hills, Calif, USA, 1980.

[40] B. Kogut and H. Singh, "The effect of national culture on the choice of entry mode2," Journal of International Business Studies, vol. 19, no. 4, pp. 411-432, 1988.

[41] A. H. L. Slangen and R. J. M. van Tulder, "Cultural distance, political risk, or governance quality? Towards a more accurate conceptualization and measurement of external uncertainty in foreign entry mode research," International Business Review, vol. 18, no. 3, pp. 276-291, 2009.

[42] M. Yamin and S. Golesorkhi, "Cultural distance and the pattern of equity ownership structure in international joint ventures," International Business Review, vol. 19, no. 5, pp. 457-467, 2010.

[43] R. Hoffman and J. Preble, "Global diffusion of franchising, A country level examination," Multinational Business Review, vol. 9, pp. 66-75, 2001.

[44] N. Alexander, M. Rhodes, and H. Myers, "International market selection: measuring actions instead of intentions," Journal of Services Marketing, vol. 21, no. 6, pp. 424-434, 2006.

[45] S. Djankov, R. La Porta, F. Lopez-de-Silanes, and A. Shleifer, "Courts," Quarterly Journal of Economics, vol. 118, no. 2, pp. 453-517, 2003.

[46] D. Welsh and I. Alon, International Franchising in Emerging Markets, Central and Eastern Europe and Latin America, CCH, Chicago, Ill, USA, 2001.

[47] H. G. Barkema and F. Vermeulen, "International expansion through start-up or acquisitions: A learning perspective," Academy of Management Journal, vol. 41, pp. 7-26, 1998. 


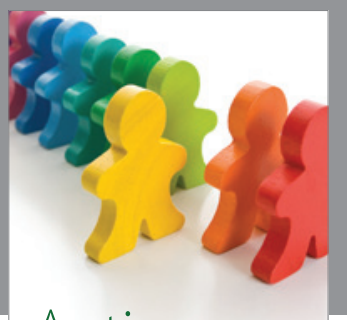

Autism

Research and Treatment
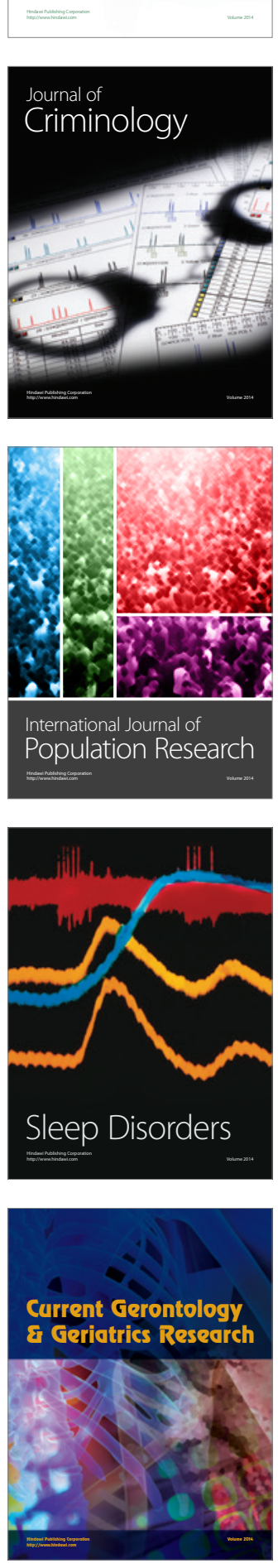
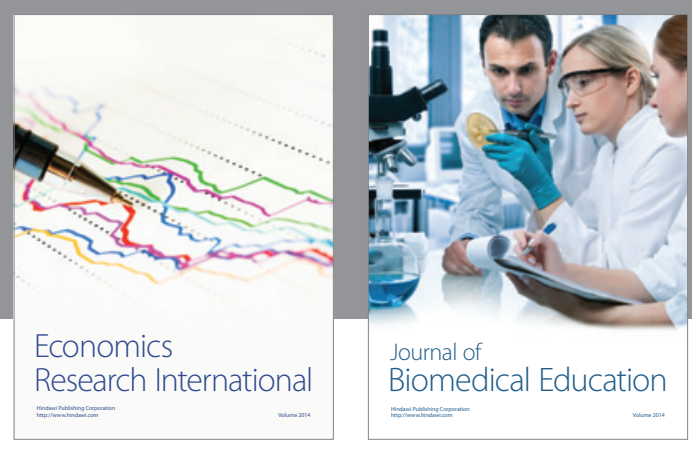

Journal of

Biomedical Education

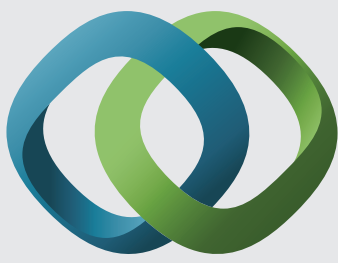

\section{Hindawi}

Submit your manuscripts at

http://www.hindawi.com
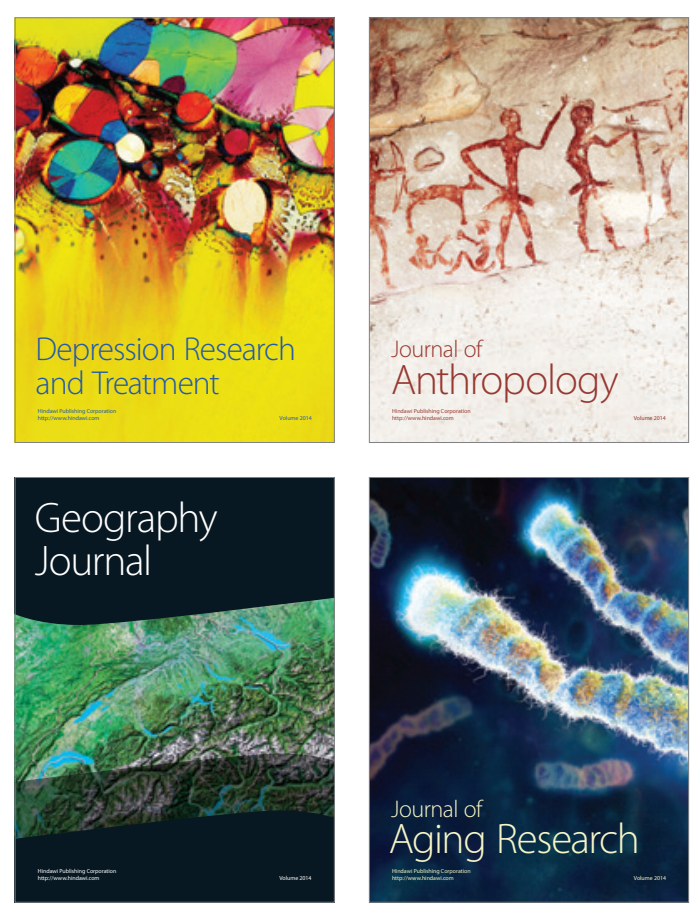

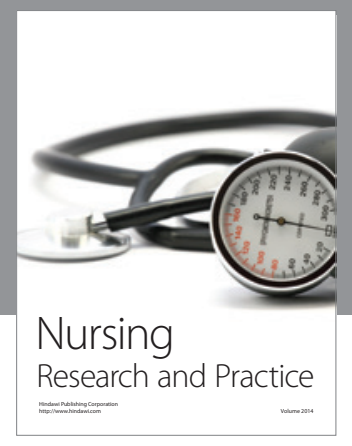

Nursing

Research and Practice

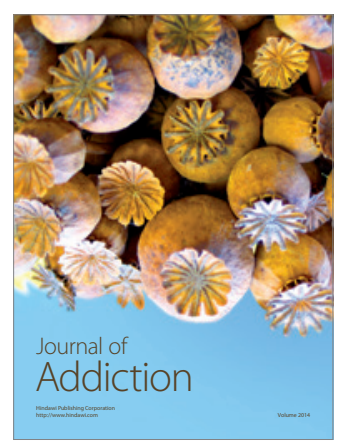

Child Development

Research

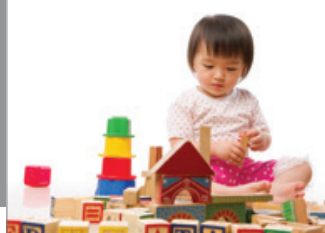

迥
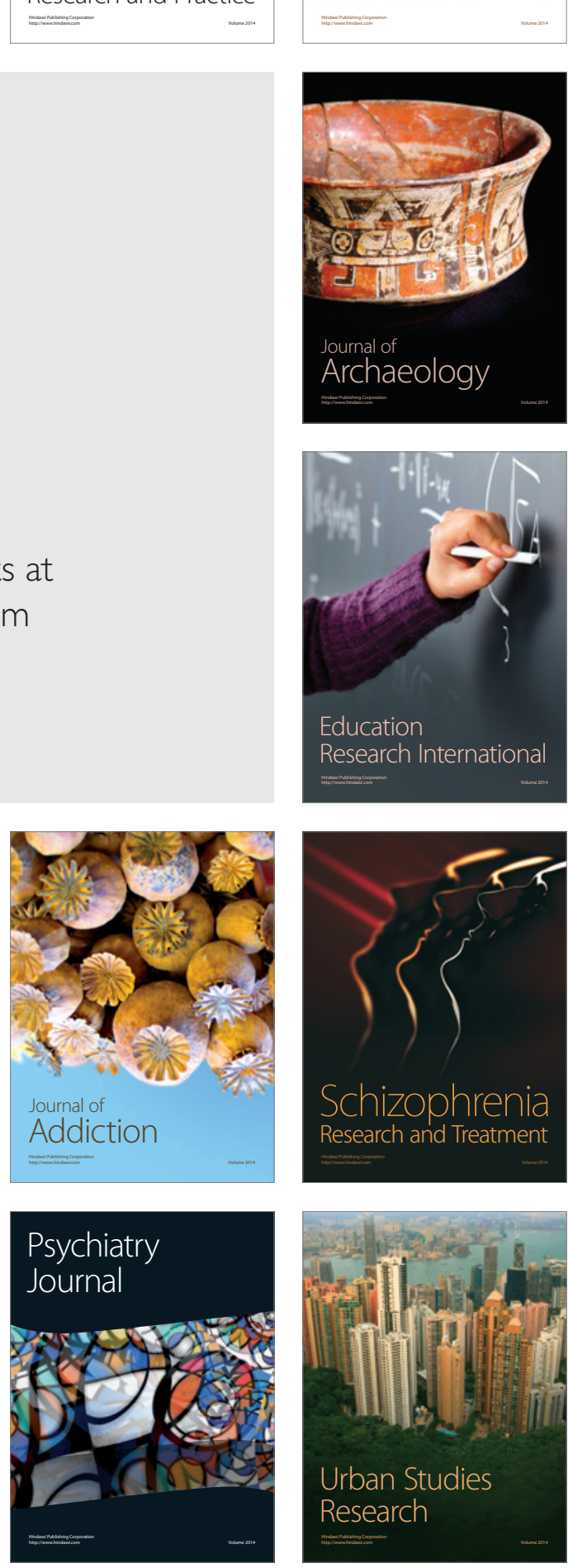